\section{Deciding ESA's future}

\section{London}

MINISTERS from the 13 countries that form the European Space Agency (ESA) will gather in Munich next week to consider Europe's future in space - the first meeting of its type since the Hague conference of 1987 (see Nature 330, 195; 1987), when the ESA states (apart from Britain) agreed to support an ambitious manned space programme, including the reusable space vehicle Hermes and Columbus, ESA's contribution to the US-led space station Freedom. But much has changed since 1987, a time of economic plenty across most of Europe, and ESA's director-general, Jean-Marie Luton, must know that his plans to increase spending on its two flagship manned programmes will be opposed by several delegates in Munich.

Luton is seeking a budget that would complete the Columbus programme for about $\$ 5,300$ million (at 1990 prices), 14.2 per cent more than the figure agreed at The Hague. This increase is due to delays imposed because of the ESA member states' desire to reduce spending in the early stages of the project (see Nature 353, 491; 10 October 1991). The total cost of Hermes, under Luton's proposal, would be about $\$ 7,600$ million, some 40 per cent more than agreed four years ago. Again, more than half of this increase is due to the extension of the programme.

Already, signs of discontent are emerging. Norway is expected to announce its withdrawal from Hermes - not a major financial problem for ESA, as Norway contributes only 0.2 per cent of the project's total cost, but just the sort of signal to other wavering nations that ESA's management was hoping to avoid.

The position of the host nation is likely to be a crucial factor in Munich. The costs of German unification have imposed a strict limit on the budget that research minister Heinz Riesenhuber has available for space, leaving him with the difficult job of balancing Germany's future in ESA against national programmes and collaborative projects with the United States and the Soviet Union. The research ministry will not reveal the precise budget ceiling beneath which Riesenhuber has to operate, but the figure is understood to be too low to cover all of Germany's planned space projects.

During the summer, Riesenhuber signalled a tough line when he said that Germany may pull out of Hermes (see Nature 352, 177; 11 July 1991), and, says Jan Baldem Mennicken, a senior research ministry official, "that still reflects one of the options." But ESA officials do not expect Riesenhuber to go that far - Hermes is a French-led project, and Germany's withdrawal would be seen as a serious affront to the French government that could provoke reprisals, damaging ESA projects favoured by the Germans.

Nevertheless, Riesenhuber will be looking for savings in the German contribution to ESA, if Germany's other space interests are not to suffer. And if he fails to find savings in Munich, the meeting's repercussions will spread beyond ESA, threatening the CRAF mission (a collaborative project with the United States to study a comet and the asteroid belt) and a series of collaborations with the Soviet Union, many inherited from former East Germany. Planned collaborations with the Soviet Union now make up almost 30 per cent of Germany's space science spending outside of ESA - about twice the proportion before unification.

Manfred Otterbein, who is responsible for space science at DARA, the German space agency, suggests that any cuts in Germany's space science budget will be a political matter and will reflect the German government's priorities in international relations more than the programmes' scientific content. Mennicken, at the research ministry, disputes this assessment, but political considerations are likely to loom large. Cutting back the proposed German- Soviet collaborations would hit scientists and engineers in former East Germany particularly hard, acting against the German government's current policy of investing in research institutes in the east of the country to bring the eastern scientific infrastructure up to western standards (see Nature 352, 267; 25 July 1991). Some savings may be possible, as several Soviet space missions are expected to fall victim to the political and economic uncertainty in that country, but the two main collaborations involving Germany - the Mars 94 and Mars 96 planetary science missions - are thought to be reasonably secure.

This makes the CRAF mission (for which the Germans are supposed to provide some scientific instruments and a propulsion system) look vulnerable. Germany is due to spend some DM120 million (about $\$ 73$ million) on CRAF, with more than DM20 million of this planned for 1992-93. But Mennicken says that the research ministry cannot tell if it can afford to contribute to CRAF over the coming year until after the ESA meeting.

A delay in funding CRAF for a year will not be harmful, as the United States is also delaying its part of the programme, but holding off for longer than that could put CRAF in jeopardy. So next week's ESA meeting will be watched closely by US space policy analysts, as well as their counterparts in Europe.

Peter Aldhous

\section{Burt files reopened}

London

UNDER pressure from ten of its fellows, the British Psychological Society is reconsidering its 1980 public discrediting of Sir Cyril Burt, the author of controversial publications on the inheritance of intelligence in children.

Burt, who died in 1971, was responsible in the 1930s for pioneering studies demonstrating high correlations between the IQ scores of pairs of monozygotic twins who had been raised in separate homes. But in 1976, the Sunday Times published an article alleging that Burt had fabricated data in some of his studies and that two women listed as research assistants for the project had never existed. The British Psychological Society eventually agreed that Burt was guilty of deception in at least three of

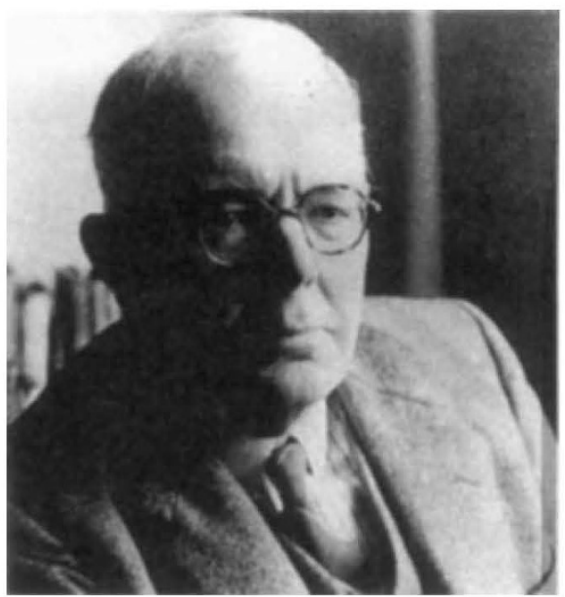

Cyril Burt's alleged fraud will be reconsidered.

his publications.

Last month, however, the society's council asked two of its members - Peter Smith, from the University of Lancaster, and Ed Miller, a clinical psychologist at the UK Department of Health - to look again at the Burt affair, to see if the society should formally reopen its investigation. The move followed the request to reconsider the Burt case from the ten society fellows and the publication of two books that sought to clear Burt's name (see $\mathrm{Na}$ ture 340,$340 ; 1989$ \& 352, 120; 1991). These argued that any inconsistencies in Burt's published data were the genuine mistakes of an old man, and produced evidence that the missing research assistants did exist.

Bill Wall, a retired child psychologist who has led the campaign within the British Psychological Society to reinstate Burt, argues that his discrediting was politically motivated, coming from psychologists who opposed Burt's ideas on the inheritance of intelligence. On the basis of the latest evidence, "you can disagree with Burt, but you can't say that he was a fraud," Wall maintains. Smith and Miller aim to finish their report by February 1992.

Peter Aldhous 